\title{
Monetary Policy, Fiscal Policy and Capital Structure
}

\author{
ZIA UR REHMAN \\ Assistant Professor, University of Haripur \\ PhD Scholar, Bahria University, Islamabad \\ zia.rehman@uoh.edu.pk \\ ASAD KHAN \\ Lecturer, University of Haripur \\ asadkhan@uoh.edu.pk \\ SHER ALI KHAN \\ PhD Scholar, Durham Business School, Durham University \\ sher.a.khan@durham.ac.uk \\ SHAH RAZA KHAN \\ IQRA National University
}

\begin{abstract}
Instruments of monetary and fiscal policy are beyond the control of the management but they do influence the short-term as well as long-term decision making of the firm. Empirical studies with respect to their effect on financing decisions of the firm are somewhat under researched particularly in the context of developing countries. The aim of the study was to analyse the effect of these instruments on the financing decisions of the non-financial firms listed on PSX for the period 2008-2015. Fixed effect model was used to analyse the effect of instruments of monetary policy and fiscal policy on the financing decisions of firms. Based on sample of 338 firms, the findings of the study revealed that instruments of monetary policy and fiscal policy do influence the financing decisions of the firm. M2, tax revenue and government debt has a significant effect on the debt ratio of listed firms whereas real interest rate is insignificantly related. Moreover, the relationship between real interest rate, M2 and tax revenue and debt ratio is negative whereas in case of government debt it is positive.
\end{abstract}

Keywords: Monetary policy, Fiscal Policy, Debt ratio, Tax revenue, Government Debt, Real interest rate, $M 2$

\section{Introduction}

The selection of appropriate financing choice by the firm has substantial significance in the long-term success of the firm. There are several factors including internal and external that affect the capital structure of a firm. As a matter of fact, the influence of internal factors can be controlled by the management whereas the influence of external factors cannot be managed by the managers. Furthermore, the knowledge about these factors with respect to their direction, level and extent of their impact will help firms make better financial decisions that will not only ensure financial stability but also growth in the long-term (Mokhova \& Zinecker, 2014). In the financial literature, we find a number of theories that helps us in explaining the behaviour and preferences of a firm for a particular choice of financing. Among them are two main theories i.e. The Trade-off Theory and Pecking Order Theory that are consistently 
applied by researchers in their capital structure studies. Trade-off theory originated from the discussion on the Modigliani and Miller irrelevance theorem (Modigliani \& Miller, 1963). The addition of corporate income tax to the original irrelevance theorem led to the creation of benefit of debt. The theory assumes that there is an optimal capital structure if a firm trades off the cost and benefit of both equity and debt financing by taking into consideration the cost of financial distress, tax shield advantages and agency costs.

Pecking order theory, introduced by Myers and Majluf in 1984, is based on the concept of asymmetric information between the investors of the firm and its managers. The theory assumes that firm follow an order while making their financing choices. Internal financing is preferred over external financing and in case where internal funds are insufficient to meet the financing needs, external debt is preferred over external equity. The study of these theories not only helps us in understanding corporate capital structure but also helpful in identifying potential factors both internal and external that may influence financing decisions of the firm. The financial literature consists of numerous studies that identified the determinants of capital structure. The review of these studies revealed that there are several internal factors that significantly influence the financing choice of a firm: firm size (Korajczyk \& Levy, 2003; Hanousek \& Shamshur, 2011; Nguyen \& Wu, 2011; Lim, 2012), profitability (Bastos, Nakamura, \& Basso, 2009; Bokpin, 2009; Dincergok \& Yalciner, 2011; Keshtkar, Valipour, \& Javanmard, 2012 and etc.), growth opportunities (Titman \& Wessels, 1988; Ozkan, 2001; Daskalakis \& Psillaki, 2008; Kouki \& Said, 2012), asset tangibility (Korajczyk \& Levy, 2003; Bastos et al., 2009; Frank \& Goyal, 2009; Nguyen \& Wu, 2011, non-debt tax shields (Ozkan, 2001; Korajczyk \& Levy, 2003; Kouki \& Said, 2012; Lim, 2012).

The findings of these studies revealed that there is mixed evidence as far as the effect of these factors on the financing choice of the firm is concerned. The derived relationships between these internal factors and capital structure are positive as well negative, significant and insignificant considering the country's specifics and the structure of debt. More recently, financial researchers have focussed on investigating the influence of external factors on the financing choice of the firm. Rajan and Zingales (1995) were probably the first ones who emphasize on the importance of external factors and their impact on financing decisions. Booth, Aivazian, DemirgucKunt and Maksmivoc (2001) identified that inflation, development of capital markets; GDP growth rates etc. are important factors that affect the financial decisions of the firm. Similarly, Gajurel (2006) revealed that the fiscal and monetary policy of a country play an important role in influencing the financing decisions of the firm.

The external environment plays an important role in the long-term future of the firm. Stable and favourable external environment will enable a firm to make effective decisions both investment and financing that will ensure long-term success and creation of firm value. However, financing decisions cannot be made in isolation. Both internal and external factors are important as they have a significant influence on financing decisions of the firm. Since, external factors (monetary and fiscal) are beyond the control of management therefore, it is important to get deeper understanding as far as how they influence financing decisions of the firm particularly in a developing country like Pakistan where external environment is quite challenging as a result of poor law and order situation, energy crisis, rising production costs, devaluation of currency etc. 


\subsection{Monetary policy}

Monetary policy is a policy set by the central back of a country to control the supply of money in circulation. The main objective of the monetary policy is to stabilize the economy by targeting inflation rate or changing interest rates. Broadly speaking, there are two common types of monetary policy i.e. expansionary and contractionay. In expansionary monetary policy, total money supply increases by lowering the rates of interest that positively influences growth rates and reduces unemployment. On the other hand, a contractionary monetary policy focuses on controlling inflation. Interest rates are raised to decrease money supply in order to control inflation. Generally, it has been observed that in periods of rising interest rates, profit oriented banks are expected to increase loans made to the private sector, thus firm level leverage should rise. In periods of economic growth, firms experience greater profits, thus enabling firms to use internally generated funds for financing. Whereas in periods of economic slowdown and declining interest rates, bank loans to private sector tends to decrease thus, resulting in decline firm level leverage.

Since the monetary policy aims to stabilise prices by controlling inflation and ensure economic growth, interest rate is the key monetary policy instrument that is used in this regard. Inflation is an important factor that significantly affects the cost of living. Furthermore, credit and reinvestments risks are influenced by expected changes in inflation rates. It is widely agreed that rising inflation rates tends to have an adverse effect on the debt and stock markets, consequently, investors expect a higher rate return thus adversely affecting the security prices. As a result, the cost of capital increases, which may make some investment projects unattractive and thus adversely affecting economic growth, rates as well stock markets. Hence, during the periods of higher inflation, debt will be more beneficial because the real cost of debt decreases whereas the cost of equity increases. Interest rates also significantly affect leverage levels of the firm. Increase in interest rates may lead to higher debt levels as there will be more tax shields advantages for the firm to exploit, but at the same time, rise in interest rate may lead to fall in leverage levels in order to reduce the cost of financial distress. Demand for money by the private sector is significantly influenced by changes in monetary policy which not only affect the equilibrium in financial markets but may also lead to changes in financial channels as well as financial constraints.

\subsection{Fiscal policy}

Fiscal policy is associated with government spending and taxation. The purpose of the fiscal policy is to stabilize the economy by implementing appropriate spending and taxation policies. In short run, the objective of the fiscal policy is to control inflation and decrease excessive unemployment whereas in the long run the focus is on encouraging economic growth in order to improve the standard of living. Changing government spending and changing taxation rates are the two common tools of fiscal policy that are used by government. Fiscal policy also can be expansionary as well as contractionay. An expansionary fiscal policy is one in which the aggregate demand is increased by the government as a result of either increase in spending or decrease in taxes or both. Decrease in taxes may result in lower tax shields on debt financing but at the same time, increase in government spending may result in higher sales and earnings which will increase internally generated funds for financing. As a result, leverage levels are going to decline at firm level. Government resorts to borrowing when it is facing budgetary deficit and it is not advisable to further increase taxes or reduce spending. The development of efficient financial markets is encouraged in places where there is an efficient government debt market. 
The development of financial markets is not only important promoting economic growth but also provides long-term financing to the firms (Das, Papapioannou, Pedras, Ahmed \& Surti, 2010).

\section{Literature Review}

Empirically, several authors have attempted to investigate the relationship between external factors and capital structure. Studies from Demirguc-Kunt and Maksimovic (1999), Korajczyk and Levy, (2003), De Jong, Kabir and Nguyen (2008), Camara (2012), Fan, Titman and Twite (2012) while exploring the effect of external factors on leverage decisions concluded that external factors significantly influence leverage decisions of the firm. Interest rates and inflation rates are the two most common external factors that have been used in these studies while analysing their relationship with capital structure. Since interest rates are indexed to inflation, a rise in inflation rate leads to a rise in interest rate and vice versa. The empirical evidence with respect to both these external factors and their relationship with capital structure is rather mixed. Studies from Noguera (2001), Hanousek and Shamshur (2011), Lemma and Negash (2013) reveal a positive relationship between inflation rate and leverage. They further explained that rise in inflation rate leads to a rise in interest rate which encourages firm to borrow as there will be more tax shield advantages to exploit and vice versa. Whereas, on the other hand, studies from Booth et al., (2001), Gajurel (2006), Dincergok and Yalciner (2011), Baltaci and Ayaydin (2014) revealed that there is a negative relationship between inflation rate and leverage. Furthermore, Bastos et al., (2009) concluded that there is no relationship between inflation rate and leverage.

Similarly, studies from Graham and Harvey (2001), Drobetz, Pensa and Wanzenried (2006), Henderson Jedadesh and Weisbach (2006) highlighted that there is a negative relationship between interest rates and leverage. Managers prefer to borrow when interest rates are lower and vice versa. On the contrary, Bopkin (2009) found positive relationship between interest rates and leverage. At the same time, Handoo and Sharma (2014) concluded that short-term as well as long-term interest rates are not significantly related. Another external factor that has been used in empirical studies is public debt. Government borrows when it is facing budgetary deficits. Borrowing by the government from the financial markets affects the supply of funds to be available for private sector to borrow. Empirical findings of Dincergok and Yalciner (2011) reveal that there is a positive relationship between government debt and leverage. On the other hand, Mokhova and Zinecker (2014) argue that government debt and leverage are negatively related.

Mokhova and Zinecker (2014) based on sample of developed and developing countries of Europe argued that in in emerging countries M2 is negatively related with debt ratio whereas in developed economies there is a positive and mostly significant relationship between M2 and debt ratio. Lastly, tax revenue as an external factor has also been used in empirical to measure its effect on debt ratio. Mokhova and Zinecker (2014) found positive relationship between tax revenue and debt ratio. They further explained that increase in tax revenue decreases government demand for borrowing from the financial markets which increases the availability of funds for private sector to borrow.

\section{Data and Methodology}

Since the aim of the study was to investigate the impact of monetary policy and fiscal policy on the firm's capital structure, therefore, secondary data was used for this purpose for the period 2008-2015. Data related to firm level debt was collected from 
the database of State Bank of Pakistan whereas data concerning inflation rate (GDP deflator), interest rates, M2 was collected from World Bank database. Data concerning government debt was taken from World Bank database whereas data concerning tax revenue was collected from economic survey of Pakistan. The sample comprised of all listed non-financial firms of Pakistan Stock Exchange (PSX). However, only those firms were considered that remain listed throughout the study period i.e. 2008-2015. The final sample comprised of 338 firms. Monetary policy variables used in the study are real interest rates (RIR) measured through nominal interest minus inflation rate. Inflation rate is measure through GDP deflator ${ }^{1}$ and money and quasi money (M2) measured through as a percentage of GDP. Fiscal policy comprised of variables like government debt (GD) measured through government debt as a percentage of GDP and tax revenue (TR) measured through tax revenue as a percentage of GDP.

\subsection{Estimated Model}

Panel data regression is applied to analyse the effect of monetary policy and fiscal policy instruments on the financing decisions of the firm. Panel data analysis provides major benefits while estimating the effect of independent variables on the dependent variable. These include, (1) there will be more degrees of freedom with reduced multicollinearity problems in data, (2) reducing or even eliminating estimation bias, (3) providing solid foundation for data analysis at aggregate level.

$$
D R_{i t}=\alpha_{0}+\beta_{1} R I R_{i t}+\beta_{2} M 2_{i t}+\beta_{3} G D_{i t}+\beta_{4} T R_{i t}+\mu_{i t}
$$

There are two common types of panel data models that are often used by researcher's i.e. random effects and fixed effects. The random effects model assumes that each firm's intercept is randomly drawn from a much larger population that has a constant mean value. Fixed effects model, on the other hand, assumes that the intercept of each firm differs from the other. In order to choose as to which model (random or fixed) will appropriate for our study, Hausman test is used. Hausman test (1978) is a specification that not only handles selection bias between random effects and fixed effects but also tell us which model (randon or fixed) is more appropriate. The results of Hausman test reveal that a fixed effect is more appropriate for our study.

Table 1 Hausman Test

\begin{tabular}{|c|c|c|c|}
\hline \multicolumn{4}{|c|}{$\begin{array}{l}\text { Correlated Random Effects - Hausman Test } \\
\text { Equation: Untitled } \\
\text { Test cross-section random effects }\end{array}$} \\
\hline Test Summary & $\begin{array}{l}\text { Chi-Sq. } \\
\text { Statistic }\end{array}$ & Chi-Sq. d.f. & Prob. \\
\hline Cross-section random & 61.092 & 4 & 0.014 \\
\hline
\end{tabular}

Before running regression several factor like multicollinearity and heteroscedasticity must be considered. White test was used for the detection of heteroscedasticity and issues related to heteroscedasticity were handled through assigning estimated

\footnotetext{
${ }^{1}$ In macroeconomic theory we find two common methods used to measure inflation rate. They are Consumer Price Index (CPI) and GDP deflator. For measuring inflation, CPI considers the prices of basket of goods only whereas GDP deflator considers the prices of all goods and services produce in an economy. Since the scope and application of GDP deflator is much broader as compared to CPI, therefore, GDP deflator was chosen as measure for inflation rate.
} 
generalized least squares weights. Various Inflation factors (VIF) of independent variables were calculated to find out whether multicollinearity exists or not.

Table 2 Variance Inflation Factors

\begin{tabular}{cc}
\hline Variable & VIF \\
\hline GD & 1.08 \\
RIR & 1.00 \\
M2 & 1.94 \\
TR & 1.91 \\
\hline
\end{tabular}

Multicollinerity exists when the VIF is greater than 10 (Gujrati, 2004). Values from Table 2 indicate that multicollinearity is not an issue here. Multicollinearity basically means that two or more independent variables are highly correlated. In the presence of multicollnearity, precise estimation becomes difficult because multicollinearity may lead to high R-Square, insignificant p-values and large variances and covariances.

\section{Results}

Table 3 Descriptive Analysis

\begin{tabular}{cccccc}
\hline & DR & RIR & GD & TR & M2 \\
\hline Mean & 0.19 & 0.62 & 0.61 & 0.09 & 0.41 \\
Median & 0.07 & 1.40 & 0.60 & 0.09 & 0.41 \\
Maximum & 0.99 & 7.90 & 0.64 & 0.10 & 0.44 \\
Minimum & 0.00 & -6.20 & 0.58 & 0.08 & 0.37 \\
Std. Dev. & 0.24 & 5.11 & 0.02 & 0.01 & 0.02 \\
Skewness & 1.20 & -0.08 & 0.23 & 0.35 & -0.12 \\
Kurtosis & 3.55 & 1.58 & 1.47 & 1.58 & 2.65 \\
Jarque-Bera & 515.92 & 172.21 & 215.95 & 210.20 & 15.11 \\
Probability & 0.00 & 0.00 & 0.00 & 0.00 & 0.00 \\
\hline
\end{tabular}

The above table shows the descriptive statistics of the variables. The mean value of debt ratio is 0.19 which means that the average debt ratio of non-financial firms listed on Pakistan Stock Exchange is 19\%. Moreover, the standard deviation of debt ratio which measures the deviation from mean is 0.24 . The mean value of real interest rate is $0.62 \%$ whereas its standard deviation 5.11 . The mean value of government debt is 0.61 which means that government debt of Pakistan is $61 \%$ of its GDP. The standard deviation of government debt is 0.02 . The mean of tax revenue is 0.09 which means that Pakistan's total tax revenue is only 9\% of its GDP whereas its standard deviation is 0.01 . The mean value of M2 (money supply) is 0.41 which means that the total money supply (M2) of Pakistan is $41 \%$ of its GDP. The standard deviation of M2 is 0.02 .

Table 4 Regression Analysis

\begin{tabular}{lllll}
\hline Variable & Coefficient & Std. Error & t-Statistic & Prob. \\
\hline C & 0.553 & 0.235 & 2.354 & 0.019 \\
GD & 3.786 & 0.289 & 13.078 & 0.000 \\
M2 & -3.484 & 0.305 & -11.431 & 0.000 \\
RIR & -0.010 & 0.011 & -0.767 & 0.443 \\
TR & -11.494 & 1.891 & -6.077 & 0.000
\end{tabular}




$\begin{array}{llll}\text { R-squared } & 0.671 & \text { S.E. of regression } & 0.465 \\ \text { F-statistic } & 10.078 & \text { Prob(F-statistic) } & 0.000\end{array}$

The regression results from the above table indicate that the instruments of fiscal policy have a significant influence on the financing decisions of the firms whereas with respect to monetary policy instruments, only M2 has a significant influence on the financial decisions of the firm. Moreover, M2, real interest rate and tax revenue is negatively related to debt ratio whereas government debt is positively related to debt ratio. The negative relationship between $\mathrm{M} 2$ and debt ratio means that increase in $\mathrm{M} 2$ leads to decline in debt ratio and vice versa. According to macroeconomic theory an increase in money supply leads to decline in interest rates. As a result, the tax shield advantages of using debt declines which may discourage firms to borrow as there are lower tax shields to exploit from the use of debt. Mokhova and Zinecker (2014) also concluded that in emerging markets M2 has a negative relationship with debt ratio.

Furthermore, we find a statistically strong negative relationship between tax revenue and debt ratio. Tax revenue is the primary source of revenue for the government. Theoretically, increase in tax revenue should result in decline in government borrowing and increase in private borrowing as more funds will be available for private sector to borrow. But in Pakistan the percentage of tax revenue to GDP although improving marginally, is one of the lowest in the developing world and the ever rising budget deficits and lack of fiscal discipline force the government to resort to public borrowing.

Government decision to borrow funds from the financial market increases the demand for funds which leads to rise in interest rates. Increase in interest rates not only increase the bankruptcy cost despite tax shield advantages but will also make some investment options unviable for some firms. Mokhova and Zinecker (2014) also found negative relationship between tax revenue and debt ratio. Theoretically, rise in government debt should result is decline in private sector borrowing. But here the results are surprisingly different and contrary to our expectations. The results of regression analysis indicate that debt ratio increase as government debt increase and falls as government debt decrease. A possible explanation for this surprising phenomenon can be that the decision by the government to resort to public borrowing increases the demand for funds in market which pushes the lending rates upwards. Rise in interest rates encourages profit oriented banks to increase the supply of funds in the market in order to benefit from higher interest rates prevailing in the market. Improved supply of funds not only meets the private sector demand for funds but provide increased tax shield advantages for the firms to exploit. Dincergok and Yalciner (2011) also found positive relationship between government debt and debt ratio.

Lastly, real interest rates not only have a negative but also a weak relationship with debt ratio. One of the possible reason behind this finding can be that real interest rates in Pakistan are comparatively high which discourses firms to borrow as the benefits of debt (tax shield advantages) are comparatively much lower than the associated cost of financial distress as a result of additional borrowing. Studies from Henderson et al. (2006) and Antoniou, Guney and Paudyal, (2008) also found negative relationship between interest rates and debt ratio and concluded that firms prefer debt financing when interest rates are lower and vice versa.

5. Conclusion

Since both monetary policy and fiscal policy is beyond the control of the firm, changes in monetary policy and fiscal policy may affect the firm positively and 
negatively and thus influence the decision making of the firm. The aim of the study was to analyse the effect of instruments of monetary policy and fiscal policy on the financing decisions of the non-financial firms listed on PSX for the period 20082015. The findings of the study revealed that instruments of monetary policy and fiscal policy do influence the financing decisions of the firm. M2, tax revenue and government debt has a significant effect on the debt ratio of listed firms whereas real interest rate is insignificantly related. Moreover, the relationship between real interest rate, M2 and tax revenue and debt ratio is negative whereas in case of government debt it is positive.

\section{References}

Antoniou, A., Guney, Y., \& Paudyal, K. (2008). The determinants of capital structure: capital market- oriented versus bank-oriented institutions. Journal of Financial and Quantitative Analysis, 43(1), 59-92.

Baltaci, N., \& Ayaydin, H. (2014). Firm, Country and Macroeconomic determinants of capital structure: Evidence from Turkish banking sector. Emerging Markets Journal, 3(3), 46-58.

Bastos, D. D., Nakamura, W. T., \& Basso, L. F. C. (2009). Determinants of capital structure of publicly-traded companies in Latin America: the role of institutional and macroeconomic factors. Journal of International Finance and Economics, 9(3), 2439.

Bokpin, G. A. (2009). Macroeconomic development and capital structure decisions of firms: evidence from emerging market economies. Studies in Economics and Finance, 26(2), 129-142. $\quad$ http://dx.doi.org/10.1108/10867370910963055

Booth, L.V., Aivazian, A., Demirguc-Kunt, A., \& Maksmivoc, V. (2001). Capital structure in developing countries. Journal of Finance, 56, 87-130.

Camara, O. (2012). Capital structure adjustment speed and macroeconomic conditions: U.S. MNCs and DCs. International Research Journal of Finance and Economics, 84, 106-120.

Das, U. S., Papapioannou, M., Pedras, G., Ahmed, F. \& Surti, J. (2010). Managing public debt and its financial stability implications. IMF Working Paper, WP/10/280, $1-25$.

Daskalakis, N. \& Psillaki, M. (2008). Do country or firm factors explain capital structure? Evidence from SMEs in France and Greece. Applied Financial Economics, 18(1), 87-97. http://dx.doi.org/10.1080/09603100601018864

De Jong, A., Kabir, R., \& Nguyen, T.T. (2008). Capital Structure Around The World: The Roles of Firm-And Country-Specific Determinants. Journal of Banking and Finance, 32, 1954-1969.

Demirguc-Kunt, A., \& Maksimovic, V. (1999).Institutions, financial markets and firm debt maturity. Journal of Financial Economics, 54, 295-336.

Dincergok, B., \& Yalciner, K. (2011). Capital structure decisions of manufacturing firms' in developing countries. Middle Eastern Finance and Economics, 86-100.

Drobetz, W., Pensa, P., \& Wanzenried, G. (2006). Firm characteristics, economic conditions and capital structure adjustments. Working paper, University of Basel.

Fan, J., Titman, S., \& Twite, G. (2012).An international comparison of capital structure and debt maturity choices. Journal of Financial and Quantitative Analysis, 47, 23-56.

Frank, M. Z., \& Goyal, V. K. (2009). Capital structure decisions: which factors are reliably important? Financial Management, 38(1), 1-37. 
Gajurel, D. P. (2006). Macroeconomic influences on corporate capital structure. Available at SSRN: http://ssrn.com/abstract $=899049$ or http://dx.doi.org/10.2139/ssrn.899049

Graham, J. R., \& Harvey, C. R. (2001). The Theory and Practice of Corporate Finance: Evidence from the Field. Journal of Financial Economics, 60, 187-243. Gujarati, D.N. (2004). Basic Econometrics, 4th edition, McGraw-Hill Book Co. Handoo, A., \& Sharma, K. (2014).A study on the determinants of capital structure in India. IIMB Management Review, 26(3), 170-182.

Hanousek, J., \& Shamshur, A. (2011). A stubborn persistence: Is the stability of leverage ratios determined by the stability of the economy? Journal of Corporate Finance, 17, 1360-1376. http://dx.doi.org/10.1016/j.jcorpfin.2011.07.004

Hausman, J. (1978). Specification tests in econometrics. Econometrica, 46, 12511271.

Henderson, B. J., Jegadeesh, N., \& Weisbach, M. S., (2006). World markets for raising new capital. Journal of Financial Economics, 82(1), 63-101.

Keshtkar, R., Valipour, H. \& Javanmard, A. (2012). Determinants of corporate capital structure under different debt maturities: empirical evidence from Iran. International Research Journal of Finance and Economics, 90, 46-53.

Korajczyk, R.A. \& Levy, A. (2003). Capital structure choice: Macroeconomic conditions and financial constraints. Journal of Financial Economics, 68, 75-109.

Kouki, M., \& Said, H. B. (2012). Capital structure determinants: new evidence from French panel data. International Journal of Business and Management, 7(1), 214229.

Lemma, T. T., \& Negash, M. (2013). Institutional, macroeconomic and firm-specific determinants of capital structure: The African evidence. Management Research Review, 36(11), 1081 - 1122

Lim, M. T. C. (2012). Determinants of capital structure: empirical evidence from financial services listed firms in China. International Journal of Economics and Finance, 4(3), 191-203.

Modigliani, F., \& Miller, M. (1963). Corporate Income taxes and the cost of capital: A correction. American Economic Review, 53(3), 433-443.

Mokhova, N., \& Zinecker, M. (2014). Macroeconomic factors and corporate capital structure. Procedia-Social and Behavioral Sciences, 110, 530-540.

Myers, S. \& Majluf, N. (1984). Corporate financing and investment decisions when firms have information investors do not have. Journal of Financial Economics, $13,187-221$.

Nguyen, T., \& Wu, J. (2011). Capital structure determinants and convergence. Bankers, Markets and Investors, 111, 43-53.

Noguera, J. (2001). Inflation and capital structure. Journal of Finance, 50.

Ozkan, A. (2001). Determinants of capital structure and adjustment to long run target: evidence from UK company panel data. Journal of Business Finance and Accounting, 28(1-2), 175-198. http://dx.doi.org/10.1111/1468-5957.00370

Rajan, R.G, \& Zingales, L. (1995). What do we know about capital structure? Some evidence from international data. Journal of Finance, 50, 1421-1460.

Titman, S., \& Wessels, R. (1988). The determinants of capital structure choice, Journal of Finance, 43(1), 1-19. http://dx.doi.org/10.1111/j.15406261.1988.tb02585.x 